\title{
MODELING THE ASSESSMENT OF THE CONNECTION OF MIGRATION AND ECONOMIC DEVELOPMENT: CASE OF AZERBAIJAN
}

\author{
Bayramov V. Shahin \\ Mingachevir State University, Mingachevir, Azerbaijan \\ Muradov S. Rashad, Hajiyeva A. Leyla, Aliyev S. Elnur \\ Azerbaijan State University of Economics (UNEC), Azerbaijan \\ Efendiyev J. Rufat \\ Socio-economic Research Center, Baku, Azerbaijan
}

\begin{abstract}
The purpose of this article is to model the assessment of the associated impact of migration and economic development of Azerbaijan. The indicators of the correlation between the intensity of migration and economic growth have been substantiated. Using the Granger test, the cause-and-effect relationships of migration and the country's economic development were determined. Based on the identified relationships, a polymodal complex has been built, consisting of polynomial regression models, which reflect the nature of the mutual influence between socio-economic development indicators and the intensity of migration in Azerbaijan. The hands' number of immigrants and emigrants in Azerbaijan for 2024 has been predicted considering the impact of the COVID-19 pandemic. The optimal ratio between the number of immigrants and emigrants was determined by linear optimization, ensuring GDP per capita in Azerbaijan at the level of modern economic development. The results obtained can serve as a basis for the development of a compelling state migration policy.
\end{abstract}

Keywords: Azerbaijan, migration, economy, development, emigrants, immigrants, labor resources

DOI: http://dx.doi.org/10.15549/jeecar.v8i1.653

\section{INTRODUCTION}

Before the COVID19 pandemic, and during a period of stabilization of the economic situation within conditions of sustainable development, there was an increase in the flow of migrants to
Azerbaijan from other countries (State Statistical Committee of the Republic of Azerbaijan, 2021). Over the past five years, until 2019, migration to Azerbaijan increased by $20 \%$, and as of the beginning of 2020 the number was 49,150 people (The Republic of Azerbaijan State 
Migration Service, 2021). Despite this positive trend, however, Azerbaijan's net migration balance remains negative; migration outflow persists. In many scientific studies on this topic (Yüksel et al., 2018; Wistrand, 2017; Chudinovskikh \& Denisenko, 2020), the leading causes of internal and external migration in Azerbaijan at different time periods included political and social instability, as well as the Nagorno-Karabakh conflict with Armenia. Internal and external migration of the population is also largely associated with demographic development conditions, namely access to education, employment, wages, social infrastructure, etc. (Yüksel et al., 2018; Wistrand, 2017).

According to official data, the economy of Azerbaijan is growing by almost 3\% per year (State Statistical Committee of the Republic of Azerbaijan, 2021), but according to expert opinion, the country's population does not feel stable and emigrates to other countries (Chudinovskikh \& Denisenko, 2020). According to official statistics, only $4.8 \%$ of the Azerbaijan population lives below the poverty line (State Statistical Committee of the Republic of Azerbaijan, 2021), however according to expert estimates, in reality it may be more than $20 \%$ of the population (Happiness is not in oil: why Azerbaijanis flee to Russia, 2019). Overall, Azerbaijan is characterized by all the same systemic problems as the post-Soviet countries: a large gap between the poor and the rich (Gulaliyev et al., 2018), a high level of social stratification, disproportionate incomes of the working population the city and the countryside, and so on. The key countries to which Azerbaijanis emigrated to are the Russian Federation, Ukraine, Kazakhstan, Turkey, European Union (EU) countries (State Statistical Committee of the Republic of Azerbaijan, 2021). A study by the United Nations (2020) confirmed the growing attractiveness of the EU countries for Azerbaijanis, as there are about 42 thousand migrants from Azerbaijan in Europe (United Nations, 2020). The total number of such migrants outside the country is about 1.1 million. (United Nations, 2020). On the one hand, the current situation of negative net migration flow clearly demonstrates the formation of the Azerbaijani diaspora and the presence of the potential for the development of economic and social transnational ties in the economic development of Azerbaijan. Migrants provide the "building blocks" for economic growth; they offer their knowledge, skills, and support to their countries of origin, transit, and arrival, thereby contributing to economic development. What is especially important against this background is the $20 \%$ growth of the population of Azerbaijan over the past 20 years (State Statistical Committee of the Republic of Azerbaijan, 2021). But on the other hand, the migration outflow has a perceptible effect on Azerbaijan's economic situation since the country is sorely lacking workers, especially those with skills that would meet international requirements (Gulueva, 2019; HampelMilagrosa \& Sibal, 2017).

In a way, 2020 marked a turning point for internal and external migration processes in many countries (Global Migration Data Portal, 2021). First, this is due to the beginning of the spread of the COVID-19 pandemic, which has led to the closure of borders and restrictions on internal movements due to quarantine. (Megits, Neskorodieva \& Schuster, 2020; Global Migration Data Portal, 2021). Migrants are more sensitive than other population groups to the pandemic's adverse economic impact. Many of them work in small shops, hotels or are employed in the tourism industry. It is precisely in these sectors of the economy that the pandemic's consequences have hit so hard that it is literally a matter of survival for many enterprises. In the European Union's hotel business, a quarter of those employed come from countries outside the EU, including Azerbaijan. Most of them work under shortterm contracts so they often become the first victims of layoffs. (Chudinovskikh \& Denisenko, 2020). A critical moment for many Azerbaijan migrants in 2020 was the aggravation of the military conflict with Armenia since the resumption of open hostilities has led to an increase in internally displaced persons from the territories Nagorno-Karabakh.

The radical change in migration processes under the influence of this crisis and the dual nature of the economy's impact necessitates constant monitoring of the relationship between the intensity of migration processes and changes in key indicators of the country's 
economic development. Determination of the main factors of influence and the possibility of modeling such an effect on the change in the state of the labor market, the standard of living of the population and the dynamics of the country's GDP for a further choice of the direction of economic development becomes especially important in a crisis. We focused on studying the correlation between the intensity of migration processes and indicators of the country's economic development. We have also adapted the application of the Granger test to determine the economic factors of migration intensity. An econometric model has been developed that allows diagnosing the qualitative nature of the conjugation of migration and economic development of the country, taking into account the characteristics of the national economy, its current level of activity and the destructive impact of the consequences of the COVID19 pandemic.

\section{LITERATURE REVIEW}

In the modern scientific literature, there are several main approaches to studying the relationship between migration and economic development. Most of the studies were based on systematic literature reviews and aimed to assess various data sets using modeling methods. Migration concepts related to the professional skills and knowledge of migrants have been significantly developed. Bougheas and Falvey (2018) applied a two-sector model of international trade with heterogeneous agents and financial barriers to demonstrate the impact of entrepreneurial migration on improving global production efficiency. Of particular interest are the concepts of accounting for the costs of migration. The scientific research of Lagakos et al. (2020) and Acharyya, Beladi \& Kar (2019) has been devoted to forming various models of earning income from migration and estimating the volume of migration costs for various categories migrants. But it should be noted that these studies were primarily aimed at identifying trends in migration flows in the recipient country, the donor country and on the scale of the global economy, without substantiating the qualitative characteristics of the impact of labor force movements, which make it possible to assess the threats and risks to the economy. This gap was leveled by studies aimed at identifying the qualitative parameters of the impact of migration on the state's socioeconomic development. (Yüksel et al., 2018; Wistrand, 2017; Lozej, 2019).

Many scientists have associated the intensity of migration processes and citizens' mobility with urbanization and urban development (Combes et al., 2020). Others are based on technological development and consider the interaction of technical and social factors as a single hybrid system (Tanrikulu, 2020). Simultaneously, they are focused mainly on identifying the role of economic and social factors in stimulating or developing migration (Rusakov, Rusakova \& Immis, 2019; Combes et al., 2020).

Research by Lozej (2019) was based on implementing the concept of the influence of the commodity (consumer) cycle on labor migration intensity. The main idea was to identify the nature of the relationship between employer-sponsored immigration (driven by demand) and commodity prices (Lozej, 2019). But the achievements in the modern literature on migration primarily reflect the experience of highly developed rich countries, particularly in the United States and in Europe. Against the background of intensive economic development and high-income levels, these countries have become attractive to the population of countries with middle income or lower median income, causing massive migration flows in search of a better life (Edo et al., 2018). The states-leaders of world development, using a selective approach and clearly defining priorities, seek to use international migration as a significant factor in developing national human capital, the economy and the social sphere (Edo et al., 2018). With the help of highly qualified immigrants, science, high technology, medicine, etc., are developing. And low-skilled labor from abroad provides small and medium-sized businesses with cheap labor. (Altındağ, Bakış \& Rozo, 2020).

Some scholars have noted the negative impact of migration on the recipient country, emphasizing that migration is a kind of social "catalyst" (Lozej, 2019). If the state has systemic problems in management, anti-corruption activities, there is an increase in interethnic 
tension, crime, the shadow economy, illegal employment, a decrease in efficiency and labor productivity due to the problems caused by the use of cheaper labor with the introduction of new equipment and technologies, a reduction in the level of development of national capital, etc. (Lozej, 2019).

As for the donor country, research also has highlighted the positive and negative aspects of labor migration. The benefits of migration were explained by an increase in the standard of living of the migrants themselves and their relatives and friends left at home, contributing to domestic consumer growth, which benefits the donor country's economy (Murakami, Yamada \& Sioson, 2021; Kapri \& Ghimire, 2020). Also, in their work, migrants accumulate and acquire invaluable experience in modern management in recipient countries, which, upon returning home, can be used in their further professional activities (Murakami, Yamada \& Sioson, 2021). But on the other hand, mass migration from the country, mainly if it occurs against the background of a decrease in the country's population, provokes a shortage of labor and, therefore, slows down economic development. Recently, there has been an increase in highly professional workers' migration flows, which for the donor country is fraught with brain drain and the risk of a decrease in the quality of human capital (Murakami, Yamada \& Sioson, 2021; Steinberg, 2017). It should be noted that the controversial nature of the question researchers have about the qualitative impact of migration on the economic development of the country depends primarily on the conditions and quality of the migrant labor force, the current state of the country's economy, and labor market conditions. These factors should be considered when examining the impact of migration on economic development.

Modern work examining the features of the development of migration in Azerbaijan were mainly focused on studying various aspects of labor migration in the countries of the former USSR, i.e., the directions of migration of internally displaced persons (Yüksel et al., 2018; Wistrand, 2017; Chudinovskikh \& Denisenko, 2020). The determination of the reasons for emigration from Azerbaijan, as well as the impact of migration on the world and national labor markets, social transformations (Yüksel et al., 2018; Wistrand, 2017; Chudinovskikh \& Denisenko, 2020). The research mainly assessed the structure of migration processes based on factors of the labor force's quality and priority areas of migration; the study of the features of the impact on Azerbaijan's national economy, though was missed.

\section{METHODOLOGY}

Based on a review of the literature (Rusakov, Rusakova \& Immis, 2019; Combes et al., 2020; Yüksel et al., 2018; and Wistrand, 2017), a sample of indicators has been formed to assess the conjugate impact of migration flows and economic development (Research period: 19902019):

$I M$ - Number of arrived migrants (immigrants), thousand people;

$E M$ - Number of outgoing migrants (emigrants), thousand people;

UNEMP - Unemployment rate, \%;

$W A G E$ - The ratio of the average monthly nominal wage the minimum wage;

$U N F A V$ - The percentage of employees working in unfavorable working conditions (in conditions that do not meet sanitary and hygienic standards, in difficult and hazardous working conditions or in places that are not suitable for work due to climatic conditions and on equipment that does not meet labor protection requirements), \%;

ST.SCIEN-Expenditures on science from the state budget, million dollars;

$R E S$ - Internal expenditures on research and development, million dollars;

ST.HEAL - State budget expenditures on health care, social protection, and social security, million dollars;

$D O C$ - Number of doctors of all specialties, thousand people per 10,000 population;

$B E D$ - Number of hospital beds per 10,000 people;

$P E N$ - The ratio of the average pension in the country to the minimum; 
SOC - Amounts of social payments to the people, million dollars;

SOC.UNEMP - Social benefits provided by the state to the unemployed population - the average monthly amount per person, USD;

$L I V$ - Average living area per capita, sq. m;

$G D P$ - GDP per capita, million dollars;

$I N C$ - Income of the population, million dollars;

$I N V$ - Investment in the economy, million dollars;

DOM.INV - Domestic investment in the economy, million dollars;

FOR.INV - Foreign investment in the economy, million dollars;

ST. ED - Government spending on education, million dollars;

ST. CULT - Government spending on culture, art, million dollars;

PRICE - Index of prices for consumer goods and paid services to the population, \%;

EMIT - Pollutants emitted into the atmosphere (from stationary sources and road transport), million tons;

POV - Poverty rate, \% of the total population;

$I C T$ - ICT development index;

$M O B$ - The share of the population living in the mobile coverage area in the country's total population, \%.

This list was supplemented with similar indicators characterizing the countries' economic development, which account for the majority of migrants who entered and left Azerbaijan. This is Russia, part of those who averaged $51.7 \%$ of all immigrants in Azerbaijan during the study period, part of those who left for Russia - $67.4 \%$ of emigrants. The socioeconomic situation of Georgia ( $14.2 \%$ of all immigrants and $1 \%$ of emigrants), Ukraine (5.4\% of immigrants, $5.7 \%$ of emigrants), Kazakhstan (5\% of immigrants, $10.6 \%$ of emigrants), Turkmenistan $(3.9 \%$ of immigrants, $1.1 \%$ of emigrants), Turkey (2.9\% of immigrants, $1.5 \%$ of emigrants (State Statistical Committee of the Republic of Azerbaijan, 2021, The Republic of Azerbaijan State Migration Service, 2021, The World Bank Group, 2021). For these countries, the above symbols were used for economic development indicators, only from the corresponding index: R - Russia, G - Georgia, U Ukraine, K - Kazakhstan, Turkm - Turkmenistan, Turk - Turkey.

The Granger test was used To establish causal relationships between the standardized values of a deterministic sample of conjugate indicators to determine the direction of influence and statistically confirm its significance. As part of the test implementation based on models (1), the fulfillment of the null hypothesis was verified, according to which $\beta_{1}=$ $=\beta_{p}=O$ (Ruan et al., 2018).

$$
\left\{\begin{array}{l}
y_{t}=\alpha_{0}+\sum \alpha_{j} \cdot y_{t-j}+\sum \beta_{j} \cdot x_{t-j}+\varepsilon_{t} \\
x_{t}=\alpha_{0}+\sum \alpha_{j} \cdot x_{t-j}+\sum \beta_{j} \cdot y_{t-j}+u_{t}
\end{array}\right.
$$

where $y, x$ - dependent and independent variables, indicators of economic development and migration intensity;

$\alpha_{0}, \alpha_{j}, \beta_{j}-$ regression for independent variables;

$t-j$ - lag of contingency of indicators;

$\varepsilon_{t}, \boldsymbol{u}_{t}$ - permissible model error.

The stationarity of the sample of indicators has been substantiated by the Dickey-Fuller method in the EViews 10 and their integration of the 1st (formula 2) and 2nd order (formula 3 ) (De Lizardi, 2014).

$$
\begin{aligned}
& \bar{y}(t)=y(t)-y(t-1), \\
& \bar{y}(t)=\bar{y}(t)-\bar{y}(t-1),
\end{aligned}
$$

where $y(t)$ - the level of the time series of indicators of economic development;

$\bar{y}(t)$ - integrated time series of the 1st order economic development indicator;

$\overline{\bar{y}}(t)$ - integrated time series of the secondorder economic development indicator.

Based on the established relationships, a multi-model complex was built, representing a system of functions of mutual influence between indicators using linear and nonlinear regression analysis in Statistica 12.0. Using the linear optimization method, the optimal ratio of 
immigrants and emigrants was determined. In this case, the target parameter was the maximization of the GDP per capita indicator (GDP $\rightarrow$ max), the controllable parameter was the indicator of the ratio of immigrants and emigrants.

\section{RESULTS}

Results of checking the indicators of socioeconomic development and the intensity of migration in Azerbaijan for 1990-2019. their stationarity evidenced stationarity. The probability of accepting the null hypothesis that the time series was non-stationary is $0-0.0182$; the values of this indicator are below the permissible error level of 0.05 . Based on the Granger causality test, the correlation of socioeconomic development indicators and the intensity of migration flows in Azerbaijan has a significance level of $p=0.05$ (Table 1 ). When checking the causality data, time lags of 1-4 years were used ( $L=1,2,3,4$, respectively).

Table 1: Causal relationships of the correlation of indicators of economic development and the intensity of migration in Azerbaijan for 1990-2019

\begin{tabular}{|c|c|c|c|c|c|c|c|c|c|}
\hline \multirow{2}{*}{$\begin{array}{l}\text { Direction causal } \\
\text { relationship }\end{array}$} & \multicolumn{4}{|c|}{ Prob. } & \multirow{2}{*}{$\begin{array}{l}\text { Direction causal } \\
\text { relationship }\end{array}$} & \multicolumn{4}{|c|}{ Prob. } \\
\hline & $L=1$ & $L=2$ & $L=3$ & $L=4$ & & $L=1$ & $L=2$ & $L=3$ & $L=4$ \\
\hline$I M \rightarrow G D P$ & 0.09 & 0.07 & 0.08 & $0.01^{*}$ & $P E N \rightarrow P R I C E$ & $0.04^{*}$ & 0.26 & 0.44 & 0.10 \\
\hline$E M \rightarrow G D P$ & 0.42 & 0.14 & $0.04^{*}$ & $0.02^{*}$ & $P E N \rightarrow P O V$ & $0.04^{*}$ & 0.31 & 0.49 & 0.55 \\
\hline$U N E M P \rightarrow I M$ & $0.00^{*}$ & $0.03^{*}$ & 0.11 & 0.09 & $S O C \rightarrow I M$ & $0.04^{*}$ & 0.22 & 0.18 & 0.09 \\
\hline$U N E M P \rightarrow E M$ & $0.00^{*}$ & $0.04^{*}$ & $0.03^{*}$ & 0.12 & $S O C \rightarrow E M$ & $0.02^{*}$ & 0.34 & 0.16 & 0.52 \\
\hline$U N E M P \rightarrow P E N$ & 0.53 & 0.27 & 0.20 & $0.02^{*}$ & $S O C \rightarrow U N E M P$ & 0.36 & 0.49 & $0.04^{*}$ & 0.24 \\
\hline $\begin{array}{l}\text { UNEMP } \rightarrow \\
\text { SOC.UNEMP }\end{array}$ & $0.01^{*}$ & 0.37 & 0.21 & 0.19 & $S O C \rightarrow I N C$ & $0.03^{*}$ & 0.14 & 0.23 & 0.09 \\
\hline$U N E M P \rightarrow I N C$ & $0.01^{*}$ & 0.14 & 0.60 & 0.54 & $S O C \rightarrow P R I C E$ & $0.04^{*}$ & 0.12 & 0.11 & 0.18 \\
\hline$U N E M P \rightarrow P O V$ & $0.00^{*}$ & $0.02^{*}$ & 0.14 & 0.23 & SOC.UNEMP $\rightarrow U N E M P$ & $0.03^{*}$ & $0.04^{*}$ & 0.42 & 0.37 \\
\hline$W A G E \rightarrow I M$ & $0.00^{*}$ & $0.02^{*}$ & 0.05 & 0.08 & SOC.UNEMP $\rightarrow P O V$ & $0.04^{*}$ & 0.06 & 0.34 & 0.62 \\
\hline$W A G E \rightarrow E M$ & $0.00^{*}$ & $0.03^{*}$ & $0.01^{*}$ & $0.04^{*}$ & $L I V \rightarrow P O V$ & $0.02^{*}$ & $0.04^{*}$ & 0.12 & 0.20 \\
\hline$W A G E \rightarrow U N E M P$ & 0.10 & 0.08 & $0.01^{*}$ & 0.06 & $G D P \rightarrow W A G E$ & $0.04^{*}$ & 0.13 & 0.08 & 0.34 \\
\hline$W A G E \rightarrow D O C$ & 0.07 & $0.03^{*}$ & $0.04^{*}$ & 0.12 & $G D P \rightarrow S T . S C I E N$ & $0.04^{*}$ & 0.12 & 0.17 & 0.35 \\
\hline$W A G E \rightarrow P E N$ & 0.54 & 0.81 & 0.42 & $0.04^{*}$ & $G D P \rightarrow R E S$ & $0.03^{*}$ & 0.19 & 0.16 & 0.26 \\
\hline$W A G E \rightarrow S O C$ & $0.04^{*}$ & 0.13 & 0.37 & 0.20 & $G D P \rightarrow S T . H E A L$ & $0.03^{*}$ & 0.18 & 0.34 & 0.50 \\
\hline$W A G E \rightarrow S O C . U N E M P$ & $0.04^{*}$ & 0.18 & 0.12 & 0.51 & $G D P \rightarrow L I V$ & 0.29 & $0.03^{*}$ & 0.09 & 0.12 \\
\hline$W A G E \rightarrow I N C$ & $0.00^{*}$ & $0.04^{*}$ & 0.18 & 0.34 & $G D P \rightarrow S T . E D$ & $0.04^{*}$ & 0.06 & 0.17 & 0.31 \\
\hline$W A G E \rightarrow P R I C E$ & $0.04^{*}$ & 0.19 & 0.34 & 0.25 & $G D P \rightarrow S T . C U L T$ & $0.04^{*}$ & 0.08 & 0.25 & 0.44 \\
\hline$W A G E \rightarrow P O V$ & $0.02^{*}$ & $0.04^{*}$ & 0.42 & 0.21 & $I N C \rightarrow I M$ & $0.02^{*}$ & $0.03^{*}$ & 0.10 & 0.17 \\
\hline$U N F A V \rightarrow W A G E$ & $0.03^{*}$ & $0.04^{*}$ & 0.12 & 0.37 & $I N C \rightarrow E M$ & $0.01^{*}$ & $0.03^{*}$ & $0.02^{*}$ & 0.10 \\
\hline ST.HEAL $\rightarrow B E D$ & $0.03^{*}$ & 0.37 & 0.21 & 0.46 & $I N C \rightarrow G D P$ & $0.02^{*}$ & 0.27 & 0.22 & 0.30 \\
\hline ST.HEAL $\rightarrow$ PEN & 0.54 & 0.51 & 0.38 & $0.04^{*}$ & $I N C \rightarrow P O V$ & $0.01^{*}$ & $0.04^{*}$ & $0.04^{*}$ & 0.16 \\
\hline ST.HEAL $\rightarrow S O C$ & $0.04^{*}$ & 0.34 & 0.41 & 0.29 & $I N V \rightarrow G D P$ & 0.46 & 0.35 & 0.08 & 0.04 \\
\hline $\begin{array}{l}\text { ST.HEAL } \rightarrow \\
\text { SOC.UNEMP }\end{array}$ & $0.04^{*}$ & 0.27 & 0.62 & 0.85 & $P O V \rightarrow I M$ & $0.00^{*}$ & $0.03^{*}$ & $0.03^{*}$ & 0.06 \\
\hline$P E N \rightarrow I N C$ & $0.03^{*}$ & 0.51 & 0.46 & 0.26 & $P O V \rightarrow E M$ & $0.00^{*}$ & $0.04^{*}$ & 0.05 & 0.08 \\
\hline
\end{tabular}

Prob. - the probability of accepting the hypothesis of the non-statistical significance of the relationship depending on the lag;

$L$ - time-lag;

* - marked statistically significant at $\mathrm{p}=0.05$ cause-effect relationships of the conjugation of the indicators 
Internal factors - indicators of the country's socio-economic development - play a decisive role in forming migration flows. These are indicators such as the unemployment rate, the ratio of the average monthly nominal wage in the country to the minimum wage, the number of social payments to the population, the income of the people, the level of poverty, all of which have a direct impact on migration activity in the country. In turn, indicators of the number of immigrants and emigrants have a statistically significant effect on GDP per capita.

From external factors (indicators of the economic situation of the countries, of which the largest number of immigrants is in Azerbaijan and which account for the largest part of those emigrating from Azerbaijan), no statistically significant impact on the indicators of the number of immigrants (IM) and emigrants $(E M)$ was recorded.

Table 2: Regression models of the conjugation of indicators of economic development and the intensity of migration in Azerbaijan for 1990-2019

\begin{tabular}{|c|c|c|c|c|}
\hline \multirow{2}{*}{ Model } & \multicolumn{4}{|c|}{ Adequacy Indicators } \\
\hline & $F_{\text {emp }}$ & $F_{t a b}$ & $t_{\text {emp }}$ & $t_{t a b}$ \\
\hline $\begin{array}{l}G D P=0.8038 \times I M(-4)- \\
1.4140 \times E M(-4)+0.5384 \times I N C(-1)++0.6051 \times I N V(- \\
4)-0.6429\end{array}$ & 35.74 & 2.84 & $\begin{array}{l}t(I M)=4.26 ; t(E M)=-6.11 ; \\
t(I N C)=3.11 ; t(I N V)=3.82\end{array}$ & 2.08 \\
\hline $\begin{array}{l}I M=-0.4088 \times U N E M P(-1)+0.8237 \times \\
\times W A G E(-1)+0.5290 \times S O C(-1)+0.9295 \times \times I N C(-1)- \\
0.8103 \times P O V(-1)+0.3676\end{array}$ & 19.26 & 2.64 & $\begin{array}{l}t(\text { UNEMP })=-2.93 ; t(\text { WAGE })=3.91 \\
t(\text { SOC })=3.35 ; t(I N C)=4.26 ; \\
t(P O V)=-3.74\end{array}$ & 2.07 \\
\hline $\begin{array}{l}E M=0.9717 \times U N E M P(-1)-0.7261 \times W A G E(-1)- \\
0.6120 \times S O C(-1)-0.9175 \times I N C(-1)++2.1074 \times P O V(- \\
1)-0.1175\end{array}$ & 62.83 & 2.64 & $\begin{array}{l}t(\text { UNEMP })=4.06 ; t(\text { WAGE })=-3.37 \\
t(\text { SOC })=-2.99 ; t(I N C)=-3.82 ; \\
t(\text { POV })=6.11\end{array}$ & 2.07 \\
\hline $\begin{array}{l}P E N=-0.5433 \times U N E M P(-4)+0.9156 \times \times W A G E(- \\
4)+0.7483 \times S T . H E A L(-4)-0.1632\end{array}$ & 52.56 & 3.05 & $\begin{array}{l}t(\text { UNEMP })=-3.0 ; 1 t(\text { WAGE })=4.23 ; \\
t(S T . H E A L)=3.86\end{array}$ & 2.07 \\
\hline $\begin{array}{l}\text { SOC.UNEMP }=-0.8511 \times U N E M P(-1)+ \\
+0.8329 \times W A G E(-1)+1.4789 \times S T . H E A L(-1)-0.6379\end{array}$ & 55.83 & 2.99 & $\begin{array}{l}t(\text { UNEMP })=-4.16 \\
t(\text { WAGE })=3.80 \\
t(\text { ST.HEAL })=5.21\end{array}$ & 2.06 \\
\hline $\begin{array}{l}I N C=-0.1345 \times U N E M P(-1)+0.7757 \times \times W A G E(- \\
1)+0.1435 \times P E N(-1)++0.3929 \times S O C(-1)-0.1253\end{array}$ & 15.73 & 2.78 & $\begin{array}{l}t(\text { UNEMP })=-2.68 ; t(\text { WAGE })=3.88 \\
t(P E N)=2.84 ; t(S O C)=3.35\end{array}$ & 2.06 \\
\hline $\begin{array}{l}P O V=0.8977 \times \operatorname{UNEMP}(-1)-0.2001 \times \times W A G E(-1)- \\
0.1274 \times P E N(-1)-0.5679 \times \\
\times L I V(-1)-0.3942 \times I N C(-1)+0.8118\end{array}$ & 61.54 & 2.64 & $\begin{array}{l}t(\text { UNEMP })=5.04 ; t(W A G E)=- \\
3.37 ; \\
t(P E N)=-2.93 ; t(L I V)=-4.29 \\
t(I N C)=-3.84\end{array}$ & 2.07 \\
\hline $\begin{array}{l}U N E M P=-0.3469 \times W A G E(-3)+0.2355 \times \times S O C(- \\
3)+0.3952 \times S O C . U N E M P(-1)+0.6740\end{array}$ & 81.96 & 3.03 & $\begin{array}{l}t(\text { WAGE })=-3.30 ; t(\text { SOC })=2.81 ; \\
t(\text { SOC. UNEMP })=3.86\end{array}$ & 2.07 \\
\hline $\begin{array}{l}S O C=0.2376 \times W A G E(-1)+0.6622 \times \times S T . H E A L(-1)- \\
0.0704\end{array}$ & 27.31 & 3.37 & $t(W A G E)=3.13 ; t(S T . H E A L)=5.10$ & 2.06 \\
\hline $\begin{array}{l}\text { ST. HEAL }=0.2023 \times G D P(-1)^{2}-0.4016 \times \times G D P(- \\
1)+0.0189\end{array}$ & 60.48 & 3.37 & $t\left(G D P^{2}\right)=3.22 ; t(G D P)=-4.11$ & 2.06 \\
\hline$L I V=0.4231 \times G D P(-2)^{2}-0.7952 \times G D P(-2)++0.1238$ & 39.91 & 3.37 & $t\left(G D P^{2}\right)=3.01 ; t(G D P)=-4.82$ & 2.06 \\
\hline $\begin{array}{l}W A G E=0.3041 \times U N F A V(-1)+0.1358 \times \times G D P(- \\
1)+0.5540\end{array}$ & 80.52 & 3.37 & $t(U N F A V)=3.17 ; t(G D P)=2.95$ & 2.06 \\
\hline
\end{tabular}

$F_{\text {emp }}$ - empirical value of the $F$-test;

$F_{t a b}$ - the table value of the $F$-criterion at $p=0.05$;

$t_{\text {emp }}$ - empirical value of the $t$-test for the independent variable;

$t_{\text {tab }}$ - the tabular value of the $t$-test at $p=0.05$ 
Regression models were built to formalize the established relationships. If the influence of the $i$-th indicator on the $j$-th was statistically significant with more than one-time lag (for example, $\quad U N E M P \rightarrow I M, \quad U N E M P \rightarrow E M$, $U N E M P \rightarrow P O V$ and others), then the $i$-th variable with a lag - at which the most statistically significant effect was observed - was used as the independent variable.

If there were causal relationships between indicators, but they did not have a direct or indirect impact on indicators of migration intensity (ST.HEAL $\rightarrow B E D, \quad W A G E \rightarrow P R I C E$, WAGE $\rightarrow D O C, \quad P E N \rightarrow P R I C E, \quad G D P \rightarrow S T . S C I E N$, $G D P \rightarrow R E S, G D P \rightarrow S T . E D, G D P \rightarrow S T .(U L T)$, then these links were not formalized using regression models (Table 2).

The empirical values of the F-criterion and tcriterion, which in modulus exceed the tabulated values at a significance level of $\mathrm{p}=$ 0.05 , testify to the adequacy of the constructed system of interconnections of the conjugation of indicators of economic development and migration in Azerbaijan.

The constructed models testify to the negative impact on the number of immigrants in Azerbaijan of such components of the country's socio-economic development as the unemployment rate, poverty level, and the positive impact of the ratio of the average monthly nominal wage in the country to the minimum wage, the number of social payments to the population and the population's income. These variables have a significant impact on the number of emigrants from Azerbaijan, but with opposite influences.

Based on the constructed regression models, the indicators of the intensity of migration flows in Azerbaijan for 2024 were predicted. The forecasting time period was determined based on the time lag associated with the power of migration flows and economic development indicators. Forecasting the number of immigrants and emigrants in Azerbaijan is based on the International Monetary Fund's estimates on the impact of the COVID-19 pandemic on the economy. For 2020, which was not included in the study sample due to the lack of all the necessary statistical data, GDP per capita in Azerbaijan decreased in dollar terms by $14.3 \%$ compared to 2019 . (International Monetary Fund, 2021).

According to the causal relationships identified by the study results, a decrease in the GDP per capita indicator will lead to a decrease in all aspects of economic development and a change in migration indicators. As a consequence of the impact of the pandemic, the number of immigrants is predicted to decrease by $21.85 \%$ compared to 2019 (to 2.11 thousand people), an increase in the number of emigrants by $34.57 \%$ (to 2.15 thousand people), and the formation of a negative balance of migration. These projected changes are due to an increase in the unemployment rate (by 3.73 percentage points compared to 2019) and poverty (by 2.72 percentage points), a decrease in the ratio of the average monthly nominal wage to the minimum wage (by $3.58 \%$ ), social payments (by $11.46 \%$ ), household income (by 9.52\%). A decrease in the number of immigrants and an increase in emigrants will affect the GDP per capita indicator, for which, over the next 4 years, a decrease of $7.44 \%$ was predicted compared to 2020 due to a negative migration balance. Other indicators remain unchanged, primarily investments that can offset the negative impact of migration. The ratio between the number of immigrants and emigrants has been determined, providing an annual increase in the GDP per capita indicator by $1 \%$, with the level of other indicators unchanged, at 2.47 times. Simultaneously, the actual indicator for 2019 was 1.69 times, and the forecast for 2024 is 0.98 times.

\section{DISCUSSION AND CONCLUSION}

A system of polymodal regression models has been developed in this study to assess the conjugation of the intensity of migration flows and the country's economic development in modern conditions. In contrast to Rusakov, Rusakova \& Immis (2019) and Combes et al., (2020), which simulated the impact of the level of socio-economic development of countries on the intensity of migration, and Lozej (2019), Murakami, Yamada \& Sioson (2021) and Kapri \& Ghimire (2020), in which the impact of migration on socio-economic development was modeled, the proposed approach allows us to 
assess the conjugation of the impact of migration intensity and socio-economic development. The practical value of the constructed model lies in its predictive function - predicting the intensity of migration flows based on indicators of socio-economic development in the country. Because the Granger test, the method of regression analysis, and linear optimization are taken together, these methods made it possible to identify the causality of relationships and economically formalize them, which made it possible to predict migration activity indicators. In determining the optimal ratio of immigrants and emigrants when balancing the positive and negative effects of migration flows.

It was substantiated that under the existing conditions and the level of internal and external migration flows, and the economic development of Azerbaijan, the dual nature of the movement of labor resources on the national economy was also manifested. A significant positive effect of attracting foreign workers is to reduce the cost of labor and the overall costs associated with its use. Consequently, for a developing market, where a negative migration flow is being traced, it seems appropriate to stimulate the number of labor immigration, facilitating the prompt satisfaction of the resulting deficit, especially for small and medium-sized businesses. Also, taking into account the specifics of Azerbaijan's modern economy, it is necessary to stimulate the same higher-quality nature of labor migration.

On the other hand, emigration at the current level in Azerbaijan has a destructive effect on the level of income of the country's population as a result of the reduction in the labor force and, in many cases, its qualifications. This can be explained by the fact that in modern conditions, the population of Azerbaijan immigrates at an economically active age, but at the same time includes both low qualifications and highly qualified specialists. Therefore, the country's government must ensure an effective migration policy. According to our study results, to provide an annual growth of the GDP per capita by $1 \%$, the number of immigrants should exceed the number of emigrants by a factor of 2.47. Of course, when the indicators of socio-economic development change, this optimal level of the ratio of migration flows also can change.

When assessing the interconnection of labor migration and economic development in Azerbaijan due to the impact of the COVID-19 pandemic, only the economic component of the pandemic's impact on migration processes was taken into account. In the future, our research priority will be to study the creation of a system of indicators for the comprehensive impact of the movement of labor resources on various aspects of the economic and social development of the state.

\section{REFERENCES}

Acharyya, R., Beladi, H., \& Kar, S. (2019). Trade, migration costs and asymmetric migration patterns. The World Economy, 42, 9, 26292648. https://doi.org/10.1111/twec.12832

Altındağ, O., Bakış, O., \& Rozo, S.V. (2020). Blessing or burden? Impacts of refugees on businesses and the informal economy. Journal of Development Economics, 146, 102490. https://doi.org/10.1016/j.jdeveco.2020.1024 90

Bougheas, S., \& Falvey, R. (2018). Entrepreneurial Migration in an Integrated World. The Scandinavian Journal of Economics, 120, 4, 1171-1201. https://doi.org/10.1111/sjoe.12249

Chudinovskikh, O., \& Denisenko, M. (2020). Labour Migration on the Post-Soviet Territory. In M. Denisenko, S. Strozza \& M. Light (Eds.), Migration from the Newly Independent States. Societies and Political Orders in Transition (pp. 55-80). Springer, Cham. https://doi.org/10.1007/978-3-03036075-7_4

Combes, P.-P., Démurger, S., Li, S., \& Wang, J. (2020). Unequal migration and urbanisation gains in China. Journal of Development Economics, 142, 102328.

https://doi.org/10.1016/j.jdeveco.2019.01.00 9

De Lizardi, C.G. (2014). A Computer Program to Run a Monte Carlo Experiment: A DickeyFuller Distribution. Economía Informa, 387, 68-75. 
Edo, A., Ragot, L., Rapoport, H., Sardoschau, S., \& Steinmayr, A. (2018). The Effects of Immigration in Developed Countries: Insights from Recent Economic Research. CEPII Policy Brief, 22.

http://www.cepii.fr/pdf_pub/pb/2018/pb20 18-22.pdf

Global Migration Data Portal. (2021, January 11). Migration data relevant for the COVID19 pandemic.

https://migrationdataportal.org/themes/mig ration-data-relevant-covid-19-pandemic

Gulaliyev, M., Ismayilzade Aliaga., Azizov, A., Kazimov, F., \& Mir-Babayev, R. (2018). Assessing the degree of inequality in the distribution of national income and its macroeconomic consequences in Azerbaijan. Amazonia Investiga, 7, 17, 85108.

Hampel-Milagrosa, A., \& Sibal, J. (2017). Addressing skills mismatch and informal employment in Azerbaijan. Global Competitiveness Report 2017-2018. Geneva.

International Monetary Fund. (2021). World Economic Outlook Database. Retrieved February 8, 2021, from https://www.imf.org/en/Publications/SPROL Ls/world-economic-outlookdatabases\#sort=\%40imfdate\%20descending

Kapri, K., \& Ghimire, S. (2020). Migration, remittance, and agricultural productivity: Evidence from the Nepal Living Standard Survey. World Development Perspectives, 19, 100198. https://doi.org/10.1016/j.wdp.2020.100198

Lagakos, D., Marshall, S., Mobarak, A.M., Vernot, C., \& Waugh, M.E. (2020). Migration costs and observational returns to migration in the developing world. Journal of Monetary Economics, 113, 138-154. https://doi.org/10.1016/j.jmoneco.2020.03.0 13

Lozej, M. (2019). Economic migration and business cycles in a small open economy with matching frictions. Economic Modelling, 81, 604-620. https://doi.org/10.1016/j.econmod.2018.07. 012
Megits, N., Neskorodieva, I., \& Schuster, J. (2020). Impact assessment of the COVID19 on trade between Eastern Europe and China. Journal of Eastern European and Central Asian Research (JEECAR), 7(3), 385-399. https://doi.org/10.15549/jeecar.v7i3.579

Murakami, E., Yamada, E., \& Sioson, E.P. (2021). The impact of migration and remittances on labor supply in Tajikistan. Journal of Asian Economics, 73, 101268.

https://doi.org/10.1016/j.asieco.2020.10126 8

Ruan, Q., Zhang, M., Lv, D., \& Yang, H. (2018). SAD and stock returns revisited: Nonlinear analysis based on MF-DCCA and Granger test. Physica A: Statistical Mechanics and its Applications, 509, 1009-1022.

Rusakov, S., Rusakova, O., \& Immis, M. (2019). Investigation of the Influence of a Number of Socio-Economic Factors on Migration Flows Between the Federal Districts of the Russian Federation. In T. Antipova \& A. Rocha (Eds.), Digital Science. Advances in Intelligent Systems and Computing (Vol. 850, pp. 36-39). Springer, Cham. https://doi.org/10.1007/978-3-030-023515_5

State Statistical Committee of the Republic of Azerbaijan. (2021). Retrieved February 5, 2021, from https://www.stat.gov.az/?lang=en

Steinberg, D. (2017). Resource shocks and human capital stocks - Brain drain or brain gain? Journal of Development Economics, 127, 250-268. https://doi.org/10.1016/j.jdeveco.2017.04.00 1

Tanrikulu, F. (2020). Impact of International Migration on Patents, Innovation, Economy and Business Strategy. In H. Dincer \& S. Yüksel (Eds.), Strategic Outlook for Innovative Work Behaviours. Contributions to Management Science (pp. 221-234). Springer, Cham. https://doi.org/10.1007/978-3-030-501310_13

The Republic of Azerbaijan State Migration Service. (2021). Retrieved February 5, 2021, from https://migration.gov.az/en/statistics 
The World Bank Group. (2021). Retrieved February 5, 2021, from https://data.worldbank.org/indicator

United Nations. (2020). International Migration 2020. Retrieved February 5, 2021, from https://www.un.org/development/desa/pd/ news/international-migration-2020

Wistrand, J.S. (2017). Social Consequences of Seasonal Labour Migration: A Case Study from Rural Azerbaijan. In M. Nikolko \& D. Carment (Eds.), Post-Soviet Migration and Diasporas. Migration, Diasporas and Citizenship (pp. 65-80). Palgrave Macmillan, Cham. https://doi.org/10.1007/978-3-31947773-2_5

Yüksel, S., Mukhtarov, S., Mahmudlu, C., Mikayilov, J.I., \& Iskandarov, A. (2018). Measuring International Migration in Azerbaijan. Sustainability, 10, 132. https://doi.org/10.3390/su10010132

Gulueva, Z. (2019). There is still a shortage of highly qualified workers in Azerbaijan. https://az.sputniknews.ru/life/20191223/42 2667376/kvalifikacija-rabotniki-rynoktruda.html

Happiness is not in oil: why Azerbaijanis flee to Russia. (2019, March 3).

https://www.gazeta.ru/business/2019/02/21 /12198475.shtml

\section{ABOUT THE AUTHORS}

Bayramov V. Shahin, email: sh.bayramov@gmail.com

Bayramov V. Shahin, Mingachevir State University, Mingachevir, Azerbaijan

Muradov S. Rashad, Azerbaijan State University of Economics (UNEC), Azerbaijan

Efendiyev J. Rufat, Socio-economic Research Center, Baku, Azerbaijan

Hajiyeva A. Leyla, Azerbaijan State University of Economics (UNEC), Azerbaijan

Aliyev S. Elnur, Azerbaijan State University of Economics (UNEC), Azarbajan 